\title{
The Integrated Plant Record (IPR) analysis: Methodological advances and new insights into the evolution of European Palaeogene/Neogene vegetation
}

\author{
Vasilis Teodoridis, Petr Mazouch, and Johanna Kovar-Eder
}

\begin{abstract}
The Integrated Plant Record (IPR) vegetation analysis serves as a proxy method to derive major types of zonal palaeovegetation based on the proportion of zonal key components. This paper pursues two goals: 1) to introduce two tools (Drudge 1 and Drudge 2) to statistically determine close modern proxies for fossil plant assemblages out of the reference set of currently 505 modern vegetation units. These range from closed forests to more open (steppe) environments from Europe and Asia and are based on the correspondence in the proportion of the zonal key components (IPR Similarity) and Taxonomic Similarity (TS, genus level); and 2) to present the extension of the calibration dataset of modern zonal vegetation using the natural vegetation of Europe, the Caucasus, China, and Mongolia. The tools are tested on six Central European plant assemblages from the late Eocene to the late Pliocene. For the late Eocene to early Miocene, the results indicate a close relationship to East Asian vegetation based both on IPR Similarity and TS. For the younger sites, IPR Similarity points towards European vegetation, whereas TS still indicates closer East Asian affinity. The summary results (as presented in the Results - Mix) derived by both tools deliver modern proxy vegetation units, which are in good agreement with modern vegetation analogues proposed by traditional empirical studies. The IPR Similarity results probably reflect climate change, which results in proportions of zonal key components, i.e., leaf physiognomy of zonal forests that are more similar to modern European than to Asian vegetation from the latest early/middle Miocene onwards.
\end{abstract}

Vasilis Teodoridis. Department of Biology and Environmental Studies, Faculty of Education, Charles University, Prague, Czech Republic. vasilis.teodoridis@pedf.cuni.cz

Petr Mazouch. Faculty of Informatics and Statistics, University of Economics, Prague, Czech Republic. mazouchp@vse.cz

Johanna Kovar-Eder. State Museum of Natural History Stuttgart, Rosenstein 1, 70191 Stuttgart, Germany. johanna.eder@smns-bw.de

Key words: fossil plants; recent vegetation proxies; methodology; Europe; Asia; (IPR) vegetation analysis

Teodoridis, Vasilis, Mazouch, Petr, and Kovar-Eder, Johanna. 2020. The Integrated Plant Record (IPR) analysis: Methodological advances and new insights into the evolution of European Palaeogene/Neogene vegetation. Palaeontologia Electronica, $23(1): a 16$. https://doi.org/10.26879/1055

palaeo-electronica.org/content/2020/2992-advances-in-ipr-analysis

Copyright: April 2020 Paleontological Society.

This is an open access article distributed under the terms of Attribution-NonCommercial-ShareAlike 4.0 International (CC BY-NC-SA 4.0 ), which permits users to copy and redistribute the material in any medium or format, provided it is not used for commercial purposes and the original author and source are credited, with indications if any changes are made.

creativecommons.org/licenses/by-nc-sa/4.0/ 


\section{INTRODUCTION}

Assessing ancient vegetation types from the fossil record has received less attention than palaeoclimate. Nonetheless, an understanding of former vegetation and its changes is essential for modelling Earth's deep-time climates. This makes former major vegetation types relevant for climate modelling, both of Earth's history and for future climate scenarios. So far, such attempts to assess former major vegetation types have played a subordinate role to other methods applied to the earth science record in assessing climate. Aside from the Integrated Plant Record (IPR) vegetation analysis (Kovar-Eder and Kvaček, 2003, 2007; KovarEder et al., 2008; Teodoridis et al., 2011b, 2012), tree diversity and vegetation have been examined based on plant functional types (Utescher et al., 2007). This concept includes climate parameters in the scoring groups (plant functional types of woody plants), but excludes herbaceous plants and does not differentiate between zonal and azonal (intrazonal) taxa. The value of the azonal taxa in assessing major vegetation types is ambiguous. An additional approach - "Plant Community Scenarios" - has been developed to assess the vegetation in northern and central Italy during the late Neogene (Martinetto and Vassio, 2009).

To further advance the IPR vegetation analysis, we introduce the new tools "Drudge 1" and "Drudge 2" to more easily determine close modern proxies of a fossil plant assemblage. This is an automated process based on the proportions of major zonal components from the modern calibration dataset and taxonomic correspondence. For this objective we also introduce the new parameter Taxonomic Similarity (TS), which is based on the taxonomic correspondence at the genus level. The calibration dataset of modern vegetation is extended to include China and Mongolia (Wang, 1961), as well as Europe and the Caucasus (Bohn et al., 2004).

\section{METHODOLOGY}

\section{The IPR Vegetation Analysis}

The IPR vegetation analysis is a semi-quantitative method to assess major zonal vegetation types based on the fossil plant record (leaf, fruit, and pollen assemblages) (Kovar-Eder and Kvaček, 2003, 2007; Kovar-Eder et al., 2008). This analysis incorporates taxonomy, physiognomy, and autecological properties of Cenozoic plants as an objective assessment of the fossil vegetation. Zonal and azonal plant taxa are assigned to basic taxonomicphysiognomic groups/components, defined to reflect key ecological characteristics of an assemblage. Teodoridis et al. (2011b) more precisely rendered the taxonomic-physiognomic grouping as follows: They divided the zonal components into conifer component (CONIFER), broad-leaved deciduous component (Figure 1) (BLD), broadleaved evergreen component (BLE), sclerophyllous component $(\mathrm{SCL})$, legume-like component (LEG), zonal arboreal palm component (ZONPALM), zonal arboreal fern component (ARBFERN), dry herbaceous component (DRY HERB, D-HERB), mesophytic herbaceous component (MESO HERB, M-HERB). Azonal components comprise azonal woody component (AZONAL WOODY), azonal non-woody component (AZONAL NON-WOODY), and aquatic component (AQUATIC). The component of PROBLEMATIC TAXA includes elements of uncertain taxonomicphysiognomic affinity.

For further analysis, all taxa (but not their abundances) of every single assemblage are assigned to those components, and their relative proportions are calculated. To characterise zonal vegetation, the following proportions of components are regarded as relevant: (a) the proportion of the BLD, BLE, and SCL+LEG components of zonal woody angiosperms, where "zonal woody angiosperms" is defined as the sum of

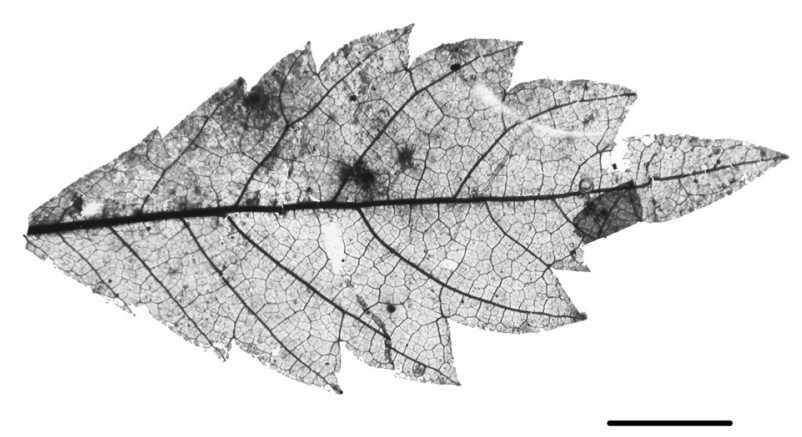

FIGURE 1. Zelkova zelkovifolia is a representative of the broad-leaved deciduous component. 
BLD+BLE+SCL+LEG+ZONPALM components; (b) the proportion of the ZONAL HERB (DRY HERB + MESO HERB) component of all zonal taxa, where "zonal taxa" are defined as the sum of the CONIFER+BLD+BLE+SCL+LEG+ZONPALM+ARBFERN+D-HERB+M-HERB components. Six basic zonal vegetation types have been distinguished: zonal temperate to warm-temperate broad-leaved deciduous forests (broad-leaved deciduous forests "BLDF"), zonal warm-temperate to subtropical mixed mesophytic forests (mixed mesophytic forests "MMF"), zonal subtropical broad-leaved evergreen forests (broad-leaved evergreen forests "BLEF"), zonal subtropical, subhumid sclerophyllous or microphyllous forests (subhumid sclerophyllous forests "ShSF"), zonal xeric open woodlands (open woodland), and zonal xeric grasslands or steppe (xeric grassland) (Kovar-Eder and Kvaček, 2007: table 2; Kovar-Eder et al., 2008: table 4).

The IPR vegetation analysis method was also applied to modern vegetation in SE China and Japan (Teodoridis et al., 2011b, 2012). Forty-seven units of different vegetation assemblages were tested using the IPR vegetation analysis, which resulted in corrections of the components' proportions in the defined major vegetation types. The results obtained from modern comparisons reflect a distinct underrepresentation of zonal herbs in the fossil record, regardless of whether preservation occurs in leaf, pollen, or fruit assemblages. The vegetation scheme based on the IPR vegetation analysis was therefore extended to properly reflect zonal herb diversity in modern vegetation. The results also confirmed a higher diversity of zonal herbs in BLDF versus BLEF as observed in the Neogene European record (Teodoridis et al., 2011b). The minimum threshold for applying the IPR vegetation analysis was recently raised from 10 to 15 zonal taxa in order to improve the reliability of the results (Kovar-Eder and Teodoridis, 2018).

\section{Calibration Datasets from the "Map of natural vegetation of Europe", China, Mongolia, and Japan}

The original calibration set of modern data from China and Japan contained 47 vegetation assemblages (Teodoridis et al., 2011b, 2012). Here we present a considerable extension (565 plant assemblages) by incorporating the modern dataset from Europe, the Caucasus (Bohn et al., 2004), China, and Mongolia (Wang, 1961). Overall, the calibration dataset currently comprises 612 mod- ern vegetation assemblages from closed to open zonal environments from Europe, the Caucasus, China, Mongolia, and Japan. The vegetation units were selected according to the presumed relevance for comparative studies with the Palaeogene and Neogene plant record of Europe. From the European vegetation, the selected zonal vegetation units are: 1) C-Subarctic, boreal, and nemoralmontane open woodlands as well as subalpine and oro-Mediterranean vegetation, 2) D-Mesophytic and hygromesophytic coniferous and mixed broadleaved-coniferous forests, 3) F-Mesophytic deciduous broad-leaved and mixed coniferous-broadleaved forests, 4) G-Thermophilous mixed deciduous broad-leaved forests, 5) H-Hygro-thermophilous mixed deciduous broad-leaved forests, 6) JMediterranean sclerophyllous forests and scrub, 7) $\mathrm{K}-$ Xerophytic coniferous forests, woodlands and scrub, 8) L-Forest steppes (meadow steppes alternating with deciduous broad-leaved forests) and dry grasslands alternating with xerophytic scrub, 9) M-Steppes, 10) N-Oroxerophytic vegetation (thorn-cushion communities, tomillares, mountain steppes, partly scrub), and 11) O-Deserts. They represent closed forest to more open vegetation types (502 plant assemblages).

Wang (1961) is apparently the most complete synthesis of the vegetation of China and therefore most suitable for this approach. Sixty-three modern vegetation units from China and Mongolia corresponding to montane boreal coniferous forest, broad-leaved deciduous forest, mixed mesophytic forest, evergreen broad-leaved forest, grassland, and desert have been added to the modern calibration dataset. Note that Wang (1961) focused on the woody flora, whereas herbs were included only occasionally (see also subheading chapter Biases).

Following the IPR vegetation analysis defaults, units bearing less than 15 zonal taxa are excluded (107 out of 612 units). Hence, 505 modern vegetation units are suitable for the analysis. The IPR vegetation analysis score lists and results for the European and Asian units are presented in Appendices 1 to 4 . Altogether they contain more than 6300 modern taxa. For the data from Bohn et al. (2004), "dominant and most frequent species" in different layers (storeys) were used to perform the IPR vegetation analysis, while taxa of the "Moss layer" were scored as PROBLEMATIC TAXA or excluded from the plant assemblages of the mapping unit " $C$ " because of their minor relevance in the fossil record. The scoring was performed mainly by VT and to a lesser extent by JK-E. Taxo- 
nomic updates of the taxa listed by Wang (1961) were done by VT, taking advantage of Flora of China - eFloras.org. The vegetation unit terms provided by the original authors are used here. Note that the acronyms BLDF, MMF, BLEF, and ShSF are widely used. When applied in the framework of the IPR vegetation analysis, we indicate this clearly. Otherwise the acronyms are applied in the sense of the respective reference.

All modern data on vegetation units from Europe and Asia have been also included in the online IPR vegetation analysis database sensu Teodoridis et al. (2011a), which is freely available on www.iprdabase.eu (Teodoridis et al. 20112019).

\section{User-friendly Applications/Tools}

Ward's method of clustering is generally widely applied, and the results are usually visualised in dendrograms, e.g., Teodoridis et al. (2011b), Kovar-Eder and Teodoridis (2018). Dendrograms may be somewhat complicated to read and are not necessarily significant at first glance. Therefore, the new applications Drudge 1 and Drudge 2 were developed as user-friendly supplements. They combine two different analytical approaches. The first approach is based on the IPR vegetation analysis and compares specific patterns of zonal key components, i.e., BLD, BLE, SCL+LEG (Drudge 1) and BLD, BLE, SCL+LEG, DRY HERB, and MESO HERB (Drudge 2). These are then scored in a fossil plant assemblage within the zonal key components of the calibration dataset of modern vegetation (see Appendices 5 and 6 , sheet "Dataset"). Mathematically, this comparison involves calculating the sums of squared Euclidian distances for all zonal components, which is expressed in equation 1. The equation follows and updates the original concept of the Ward's method in the cluster analysis, which has been applied to validate the IPR vegetation analysis in modern plant assemblages from China and Japan (Teodoridis et al., 2011b, 2012).

$$
\sum_{i=1}^{k}\left(x_{i}^{R}-x_{i}^{F}\right)^{2}
$$

where $k$ is the number of the key zonal components, $x_{i}^{R}$ is the proportion of $i$-key zonal component for modern vegetation from the reference unit, and $x_{i}^{F}$ is the proportion of $i$-key zonal component for the fossil plant assemblage.

The second analytical approach involves entering the analytical parameter of "Taxonomic Similarity" (TS). This is introduced here and reflects the taxonomic correspondence at generic level between fossil and modern plant assemblages. The parameter is calculating using all zonal components (i.e., CONIFER, BLD, BLE, SCL+LEG, ZONPALM, ARBFERN, DRY HERB, and MESO HERB) and also compares the respective fossil assemblage to modern vegetation units containing more than 15 zonal elements. Therefore, the TS is calculated as the proportion of the number of shared genera in the fossil and modern plant assemblages, and the total number of genera in the fossil plant assemblage (equation 2).

$$
\begin{gathered}
\text { number of shared genera } \\
\text { in a fossil and a modern assemblage } \\
\text { number of genera in a fossil assemblage }
\end{gathered}
$$

\section{Understanding Drudge 1 and Drudge 2}

The tools, which are introduced here, are named "Drudges" because they facilitate the applicant to retrieve modern vegetation proxies for fossil plant assemblages. As noted above, Drudge 1 displays the closeness of the studied fossil and modern plant assemblages based on their proportions of key zonal woody angiosperms, i.e., BLD, BLE, and SCL+LEG components and the parameter Taxonomic Similarity (TS) introduced here. Mathematically, Drudge 1 is designed to extract a) the highest level of correspondence in the proportions of BLD, BLE, SCL+LEG components within the total number of zonal woody angiosperms at the studied fossil site and $b$ ) the taxon correspondence on the generic level (TS) based on the above equations 1 and 2 . Drudge 2 was primarily developed to better distinguish more open vegetation types. It works on the same principle as Drudge 1 but includes the zonal herb components, i.e., percentages of DRY HERB and MESO HERB. It determines the highest level of correspondence in the proportions of the zonal woody key components, i.e., BLD, BLE, SCL+LEG, and of zonal herbs of all zonal components, i.e., CONIFER, BLD, BLE, SCL+LEG, ZONAL PALM, ARBFERN, DRY HERB, and MESO HERB, at a study site based on equation 1 . Note that Drudge 2 should be 
applied only to assemblages with sufficient evidence of zonal herbs.

An automatic "copy and paste" application independently shows three different kinds of results (Appendix 5 for Drudge 1 and Appendix 6 for Drudge 2) corresponding to 1) closeness of IPR vegetation analysis pattern of key components (sheet "Results - IPR Similarity"), 2) Taxonomic Similarity (sheet "Results - Taxonomic Similarity"), and 3) a summary of both mentioned analytical approaches (provided as the sheet "Results Mix").

The IPR vegetation analysis scoring of a given fossil plant assemblage, including its name, must first be entered in Appendix 5 (or Appendix 6) "Insert sheet" as the input dataset. In the sheet "Results - IPR Similarity" the best fitted results appear in the lines below, including the ID codes (column B) of close modern vegetation units from the calibration dataset (Appendix 5 sheet "Dataset") and the percentages of their key woody components. The best fitted results are arranged in descending order by values of the mathematical difference (see column M). The values of mathematical difference are expressed as differences in the key zonal component pattern between fossil and modern plant assemblages (equation 3 ).

$$
\sqrt{\sum_{i=1}^{k}\left(x_{i}^{R}-x_{i}^{F}\right)^{2}}
$$

where $k$ is the number of the key zonal components, $x_{i}^{R}$ is the proportion of $i$-key zonal component for modern vegetation from the reference site, and $x_{i}^{F}$ is the proportion of $i$-key zonal component for the input studied fossil plant assemblage. The maximal (hypothetical) values of mathematical difference are 141.4 for Drudge 1 and 199.0 for Drudge 2.

In Appendix 5 the sheet "Results - Taxonomic Similarity" contains the list of fossil taxa (column A) and calculated values of TS (see equation 2) expressed in \% for each modern plant assemblage from the calibration dataset, again arranged in descending order. The tool automatically identifies the genus level from the list of fossil plant taxa ("Taxon-working" sheet, column E). It then compares the names with those of each modern vegetation unit from the calibration dataset and marks the correspondence as a cross (" $x$ "). Note that TS is calculated on the generic level, based on all fos- sil zonal taxa including fractionally zonally scored ones but excluding those scored completely as azonal or problematic taxa. Users wishing to include generic names accompanied by "cf." or "aff." in the comparison of modern and fossil genera, must write these shortcuts following the whole taxon name, e.g., in brackets. Genera accompanied by a question mark or in quotation marks are automatically excluded from this comparison. The use of such supplements referring to the species epitethon does not affect the evaluation. Taxa assigned to a higher taxonomic level, e.g., family, a phenomenon especially common in the treatment of pollen, are also excluded from the taxonomic correspondence calculation. Note that multiplicate scores of genera in the fossil record are processed as multiplicate scores in the recent record. For example, if a given fossil assemblage yields three species of Pinus and the modern plant assemblage from the reference dataset contains only one pine species, then the taxonomic correspondence will be scored as 3 . If the fossil assemblage yields one species of Pinus and the modern assemblage contains three different pine species, the taxonomic correspondence will be scored as 1 .

The summarised results are presented in Appendices 5 and 6 in sheet "Results - Mix", where the best fitted modern analogues to a given fossil plant assemblage are calculated as a correspondence of the following four identically valuable parameters, i.e., \% BLD, BLE, SCL+LEG, and TS. Besides the ordering, values of IPR Similarity and TS are also presented, and the item "Total difference" is introduced, which summarises IPR Similarity, and TS in one difference expressed by equation 4 .

$$
\sqrt{\sum_{i=1}^{k}\left(x_{i}^{R}-x_{i}^{F}\right)^{2}+(100-T S)^{2}}
$$

where $k$ is the number of the key zonal components, $x_{i}^{R}$ is the proportion of $i$-key zonal component for modern vegetation from the reference site,

$x_{i}^{F}$ is the proportion of $i$-key zonal component for the given studied fossil plant assemblage, and TS the value of Taxonomic Similarity. The maximal (hypothetical) values of "Total difference" is 173.2 for Drudge 1 and 222.7 for Drudge 2. 
TABLE 1. Brief characteristics of the fossil plant assemblages from Europe selected for testing Drudge 1 and Drudge 2 (hereafter "test set"). The selected sites cover the period late Eocene to late Pliocene.

\begin{tabular}{|c|c|c|c|c|c|c|}
\hline Studied floras & $\begin{array}{l}\text { Staré Sedlo, } \\
\text { Czech } \\
\text { Republic }\end{array}$ & $\begin{array}{c}\text { Seifhennersdorf, } \\
\text { Germany }\end{array}$ & $\begin{array}{c}\text { Wackersdorf, } \\
\text { Germany }\end{array}$ & $\begin{array}{c}\text { Parschlug, } \\
\text { Austria }\end{array}$ & Sośnica, Poland & $\begin{array}{c}\text { Vonšov Mb. } \\
\text { (Vildštejn Fm.-Pluto } \\
\text { Clay), Czech } \\
\text { Republic }\end{array}$ \\
\hline GPS coordinates & $\begin{array}{l}\mathrm{N} 50^{\circ} 10^{\prime} \\
54.39^{\prime \prime}, \mathrm{E} 12^{\circ} \\
43^{\prime} 11.37^{\prime \prime}\end{array}$ & $\begin{array}{l}\text { N } 50^{\circ} 56^{\prime} 7.02^{\prime \prime}, \text { E } \\
14^{\circ} 36^{\prime} 26.99^{\prime \prime}\end{array}$ & $\begin{array}{l}\text { N 49 } 19^{\circ} 50.96 " \text {, } \\
\text { E } 12^{\circ} 10^{\prime} 39.46^{\prime \prime}\end{array}$ & $\begin{array}{l}\text { N } 47^{\circ} 28^{\prime} 50.7^{\prime \prime}, \mathrm{E} \\
15^{\circ} 17^{\prime} 15.3^{\prime \prime}\end{array}$ & $\begin{array}{l}\text { N } 51^{\circ} 01 ' 58.7^{\prime \prime} \\
\text { E16 } 47^{\circ} 00.3^{\prime \prime}\end{array}$ & $\begin{array}{l}\text { N } 50^{\circ} 9^{\prime} 19.74^{\prime \prime}, \text { E } 12^{\circ} \\
22^{\prime} 43.99^{\prime \prime}\end{array}$ \\
\hline References & $\begin{array}{l}\text { Knobloch et al. } \\
\text { (1996), } \\
\text { Teodoridis et al. } \\
(2012)\end{array}$ & $\begin{array}{l}\text { Walther and Kvaček } \\
(2007)\end{array}$ & $\begin{array}{l}\text { Knobloch and } \\
\text { Kvaček (1976), } \\
\text { Gregor (1978), } \\
\text { Günther and } \\
\text { Gregor (1993) }\end{array}$ & $\begin{array}{l}\text { Kovar-Eder et al. } \\
(2004)\end{array}$ & $\begin{array}{l}\text { Goeppert (1855), } \\
\text { Stachurska et al. } \\
\text { (1973), Walther and } \\
\text { Zastawniak (1991), } \\
\text { Zastawniak and } \\
\text { Walther (1998), } \\
\text { Collinson et al. (2001), } \\
\text { Kohlman-Adamska et } \\
\text { al. (2004); Manchester } \\
\text { and Zastawniak (2007) }\end{array}$ & $\begin{array}{l}\text { Stuchlik (1982), Bůžek et } \\
\text { al. (1985), Teodoridis et } \\
\text { al. (2017) }\end{array}$ \\
\hline Series & late Eocene & early Oligocene & early Miocene & $\begin{array}{l}\text { early/middle } \\
\text { Miocene }\end{array}$ & late Miocene & late Pliocene \\
\hline 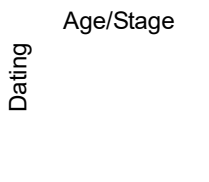 & Priabonian & Rupelian & $\begin{array}{l}\text { Burdigalian } \\
\text { (Karpatian) }\end{array}$ & $\begin{array}{l}\text { uppermost } \\
\text { Burdigalian/ } \\
\text { lowermost } \\
\text { Langhian } \\
\text { (Karpatian/early } \\
\text { Badenian) }\end{array}$ & Tortonian - Messinian & Piacenzian (Reuverian) \\
\hline Ma & $?$ & $30.44 \pm 1.25$ & $14.5-17.3$ & $?$ & $?$ & $? 2.6-4.5$ \\
\hline Fossil record & $\begin{array}{l}\text { leaves, pollen } \\
\text { (morphotaxa) }\end{array}$ & leaves & leaves, fruits & leaves & leaves, fruits, pollen & leaves, fruits, pollen \\
\hline
\end{tabular}

Appendix 7 lists the linkage of ID codes and the designation of the modern plant units. The ID codes of the modern plant assemblages are provided in column B in descending order of correspondence both in the sheets "Results-IPR Similarity" and "Results-Mix". The designations of the plant assemblages are displayed in column $\mathrm{N}$ of the sheet "Results-IPR Similarity" and in column $P$ of the sheet "Results-Mix" in the Appendices 5 and 6 for better orientation.

\section{Application of the Tools}

Drudge 1 and 2 are tested here on selected fossil assemblages from Central Europe stratigraphically covering the late Eocene to the late Pliocene. This time interval and geographical constraint were selected to test whether changes in the floristic composition of the fossil floras documenting vegetation change in deep time are also reflected in the modern vegetation units delivered by the tools introduced here. Further criteria for the choice of fossil sites were high species diversity and reasonable state of taxonomic resolution. Following these criteria, we chose the sites Staré Sedlo (late Eocene), Seifhennersdorf (early Oligocene), Wackersdorf (early Miocene), Parschlug (early/middle Miocene), Sośnica (late Miocene), and Vonšov Mb. (Vildštejn Fm.-Pluto Clay, late Pliocene) (Table 1).

The record from Staré Sedlo comprises mostly leaf remains assigned to botanical taxa (partly extinct) and some leaves and pollen treated as morphotaxa (not assigned botanically). The records from Seifhennersdorf and Parschlug include mainly leaves and some fruit remains, Wackersdorf yields both leaf and fruit records, and Sośnica and Vonšov Mb. (Vildštejn Fm.-Pluto Clay) comprise an integrated plant record of leaves, fruits, and pollen. The zonal herb record (DRY HERB and MESO HERB) varies considerably among the selected sites: Staré Sedlo $10.4 \%$, Seifhennersdorf $2.6 \%$, Wackersdorf $2.6 \%$, Parschlug $1.7 \%$, Sośnica $13 \%$, and Vonšov Mb. (Vildštejn Fm.-Pluto Clay) 33.3 \%. The application of Drudge 2 is more relevant if zonal herbs are well represented in a fossil assemblage. For the test set of fossil sites, the scoring and results retrieved by the IPR vegetation analysis are presented in Appendix 8. The results for each site based on the application of Drudge 1 and Drudge 2 are shown in Table 2, in which the most closely corresponding five modern sites are considered as "proxy set". These same results are shown in more detail in Appendices 9 and 10. 
In the calibration dataset modern vegetation is resolved to the highest degree possible in order to avoid missing any signal. This is reflected in the results derived from applying the Drudges. The vegetation units are therefore summarised to higher-order entities which are arranged according to major vegetation types based on Appendix 7 (Table 3).

\section{Biases}

Several aspects should be kept in mind when applying the new tools to derive modern vegetation proxies for fossil plant assemblages. First, the fossil plant record is always biased by site-specific taphonomic impacts (see Kovar-Eder et al., 2008), limiting the derivation of modern vegetation analogues.

When comparing IPR Similarity to Taxonomic Similarity (TS), note that the former takes advantage of leaf physiognomy including morphotaxa, whereas in TS morphogenera such as Laurophyllum, Dicotylophyllum or palyno-morphogenera, and extinct genera such as Eotrigonobalanus must be neglected because modern analogues are lacking. Hence, higher numbers of morphogenera, and species within such morphogenera in fossil assemblages, lower the correspondence with modern vegetation units. TS results also depend on the number of genera both in a fossil flora and in modern vegetation units. The TS may appear higher with modern units of high generic diversity than with sites of low diversity, reducing the differentiation potential of such units (example China 03 with more than zonal 630 species, appearing as a close modern proxy of all test sites except Staré Sedlo, Table 2). Furthermore, more than one species of a genus in a given fossil record produces a corresponding number of positive results even if only a single species of this genus occurs in the compared modern vegetation unit (see subheading Understanding Drudge 1 and Drudge 2). Thus, Quaternary post glacial extinctions in Europe and parts of Asia may bias the comparison with modern vegetation units.

Assessing modern vegetation to calibrate the fossil record must rely on the available sources. Data on modern vegetation partly derive from general descriptions, e.g., Wang (1961), Li and Shi (2007), while others are based on vegetation recording of differently sized plots, e.g., Bohn et al. (2004). The resolution of modern vegetation units also differs according to the region - from very detailed in Europe (405 units) to more large-scaled in East Asia (103 units). The comparison with higher ranks of vegetation classification is therefore also important (see Table 3). Detailed data on the herb layer are available from Europe, whereas information on vegetation units in East Asia is scarcer; this may potentially bias the comparison of the fossil versus modern record.

Generally, the set of modern units retrieved for a fossil assemblage by applying Drudge 1 and 2 should be regarded as proxies that resemble each other to some degree in IPR Similarity (percentages of zonal key components) and TS rather than as being closest modern analogues. The ongoing extension of the modern dataset, which currently includes East Asia and Europe but not yet North America, may change the results of the modern proxy sites proposed here.

\section{RESULTS}

Comparing the IPR Similarity results derived by Drudge 1 and Drudge 2 (Table 2), the maximum correspondence between the modern vegetation sets is three vegetation units (Wackersdorf: Japan 04, China 35, 37). For Seifhennersdorf the correspondence is one (China 38) as is for Stare Sedlo (China 89), whereas there is none between the results derived by Drudge 1 and Drudge 2 for Parschlug, Sośnica, and Sośnica, and Vonšov Mb. (Vildštejn Fm.-Pluto Clay).

Both tools deliver markedly different proxy sets for IPR Similarity compared to those proposed by Taxonomic Similarity (TS) (Table 2). Applying Drudge 1 yields single overlaps between the results of IPR Similarity and TS (Sośnica: (Japan 01). Applying Drudge 2 yields a similarly low overlap (Staré Sedlo: China 34, Seifhennersdorf: China 67). In Drudge 1, IPR Similarity indicates European and East Asian sites throughout from Staré Sedlo to Vonšov Mb. (Vildštejn Fm.-Pluto Clay), with an increase of European proxy sites in the floras Parschlug and Sośnica. IPR Similarity retrieved by Drudge 2 indicates exclusively East Asian proxy sites for Staré Sedlo, Seifhennersdorf, and Wackersdorf, but only European ones for Parschlug and Vonšov Mb. (Vildštejn Fm.-Pluto Clay) and mostly European ones (four of five) for Sośnica. TS delivers exclusively East Asian proxy units for all fossil sites. The Results - Mix retrieved by both tools share four units for Staré Sedlo (China 30, 34, 36, 89) and Seifhennersdorf (China $56,57,60,67$ ), three for Wackersdorf (China 03, 36,67 ) and Sośnica (Japan 06, China 60, 68), two for Vonšov Mb. (Vildštejn Fm.-Pluto Clay) (China 03, China 68), and one for Parschlug (China 03). In the Results - Mix the proxy sets derived from both 


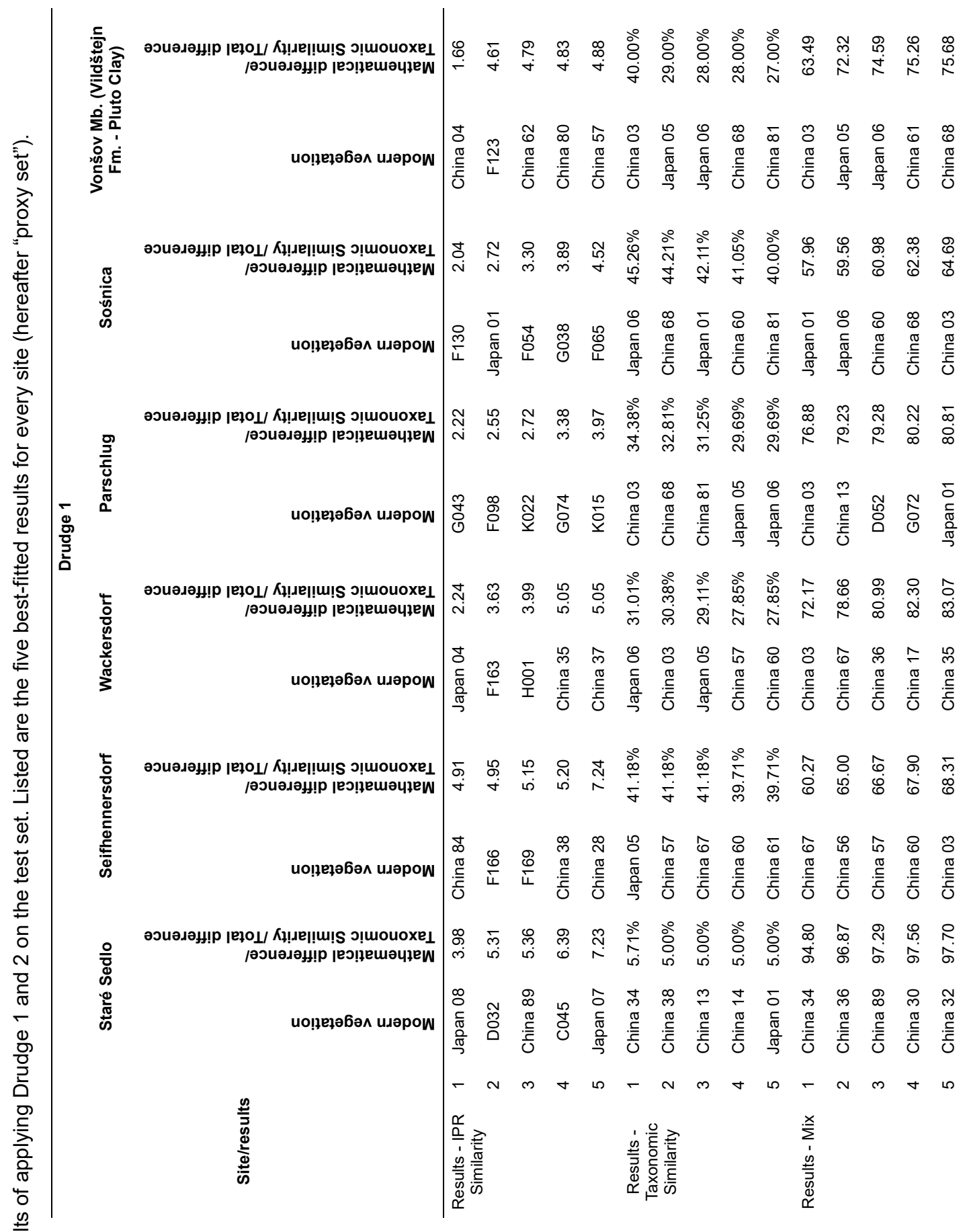




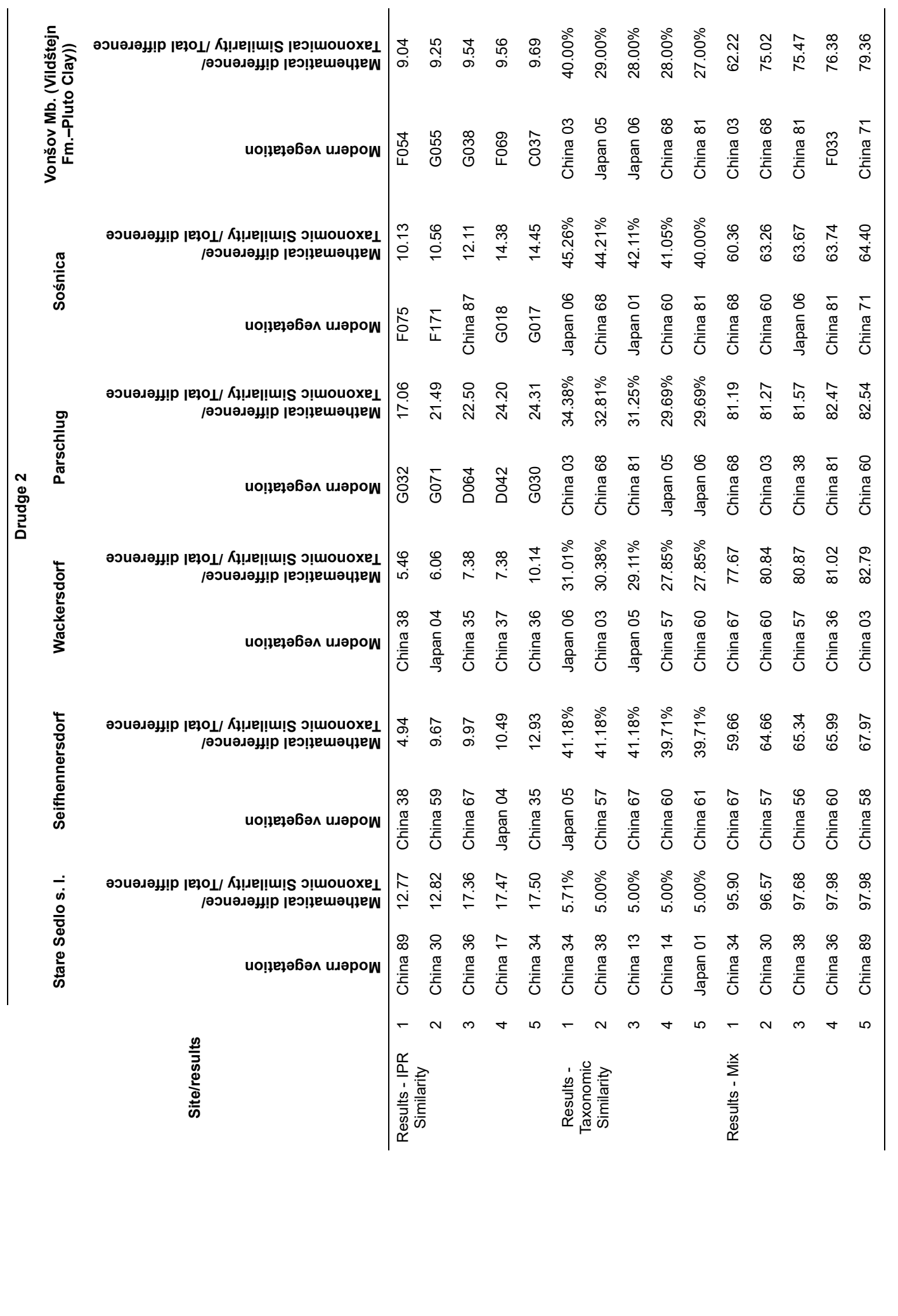


TABLE 3. Synthesis of the results derived by applying Drudge 1 and 2 . Small-scaled vegetation units are summarised to higher-order entities, which are arranged according to major vegetation types. Counts reflect the occurrences of the modern vegetation units in the proxy sets for IPR Similarity, Taxonomic Similarity (TS), and Results - Mix (Table 2). TS is counted only once.

\begin{tabular}{|c|c|c|c|c|c|c|c|}
\hline ID & major vegetation types & 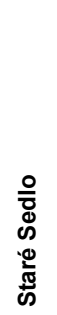 & 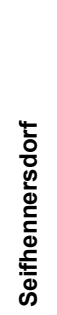 & $\begin{array}{l}\frac{t}{0} \\
\frac{0}{0} \\
\frac{0}{2} \\
\frac{0}{0} \\
\frac{0}{0} \\
3\end{array}$ & 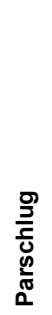 & 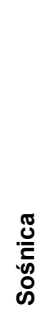 & 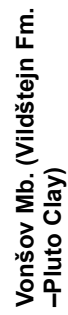 \\
\hline China $17,28,30-38$ & Broad-leaved evergreen forest, China & 14 & 4 & 10 & 1 & & \\
\hline Japan 04, 07, 08 & Broad-leaved evergreen forest, Honshu, Japan & 2 & 1 & 2 & & & \\
\hline China $56-61$ & $\begin{array}{r}\text { Mixed mesophytic forest of the Lower Yangtze } \\
\text { Province }\end{array}$ & & 11 & 4 & 1 & 3 & 2 \\
\hline China 03 & $\begin{array}{r}\text { Mt. Emei evergreen or deciduous broad-leaved } \\
\text { mixed forest zone }\end{array}$ & & 1 & 3 & 3 & 1 & 3 \\
\hline China $04,62-67$ & $\begin{array}{r}\text { Broad-leaved deciduous forest, Upper Yangtze } \\
\text { Province and Mt. Emei }\end{array}$ & & 4 & 2 & & & 2 \\
\hline China 68-79 & $\begin{array}{r}\text { Broad-leaved deciduous forests of the Northern } \\
\text { and Northeastern Provinces }\end{array}$ & & & & 2 & 4 & 4 \\
\hline Japan 01-03,05 & $\begin{array}{r}\text { Broad-leaved deciduous forests Shirakami } \\
\text { Sanchi, and Mt. Fuji }\end{array}$ & 1 & 1 & 1 & 2 & 3 & 2 \\
\hline $\mathrm{D}$ & $\begin{array}{l}\text { D Mesophytic and hygromesophytic coniferous } \\
\text { and mixed broad-leaved-coniferous forests }\end{array}$ & 1 & & & 3 & & \\
\hline $\mathrm{F}$ & $\begin{array}{r}\text { F Mesophytic broadleaved deciduous and mixed } \\
\text { broad-leaved/conifer forests }\end{array}$ & & 2 & 1 & 1 & 5 & 4 \\
\hline G & $\begin{array}{r}\text { G Thermophilous mixed deciduous broadleaved } \\
\text { forests }\end{array}$ & & & & 6 & 3 & 2 \\
\hline $\mathrm{H}$ & $\begin{array}{r}\text { H Hygrophilous thermophytic mixed deciduous } \\
\text { broadleaved forests }\end{array}$ & & & 1 & & & \\
\hline $\mathrm{K}$ & $\begin{array}{r}\text { K Xerophytic coniferous forests, coniferous } \\
\text { woodland and scrub }\end{array}$ & & & & 2 & & \\
\hline China 13,14 & $\begin{array}{l}\text { Meili Snow Mt. - Sclerophyllous and broad- } \\
\text { leaved forest zone (2580-3650 m alt) }\end{array}$ & 2 & & & 1 & & \\
\hline China $80-89$ & Montane coniferous forests, China, Taiwan & 4 & 1 & & 2 & 3 & 3 \\
\hline Japan 06 & $\begin{array}{r}\text { Mt. Fuji-Upper montane and subalpine } \\
\text { coniferous belt, } 1800-2500 \mathrm{~m}, \text { Vaccinium-Picea } \\
\text { region }\end{array}$ & & & 1 & 1 & 3 & 2 \\
\hline $\mathrm{C}$ & $\begin{array}{r}\text { C Subarctic, boreal and nemoral-montane open } \\
\text { woodlands as well as subalpine and oro- } \\
\text { Mediterranean vegetation }\end{array}$ & 1 & & & & & 1 \\
\hline
\end{tabular}

tools are dominated by modern vegetation units in East Asia.

Focusing on these shared modern units derived by applying the Drudges (Results - Mix), Stare Sedlo is comparable to the Broad-leaved Evergreen Forest from Taiwan (China 30), Broadleaved Evergreen Sclerophyllous Forest from Guangxi Province (China 34), Broad-leaved Evergreen Sclerophyllous Forest from Guizhou Prov- ince (China 36), and Montane Coniferous Forest from Taiwan (China 89).

Seifhennersdorf, in turn, is comparable to the Mixed Mesophytic Forest from Southern Jiangsu Province (China 56), Mixed Mesophytic Forest of Tiantai-Shan from the Zhejiang Province (China 57), Mixed Mesophytic Forest from Southern Anhui Province (China 60) and Broad-leaved Deciduous Forest from Eastern Guizhou Province (China 67). 
Wackersdorf resembles the Evergreen/Deciduous Broad-leaved Mixed Forest zone of Mt. Emei (1500-2000 m alt., Li and Shi, 2007) (China 03), Broad-leaved Evergreen Sclerophyllous Forest from Guizhou Province (China 36), and Broadleaved Deciduous Forest from Eastern Guizhou Province (China 67).

Parschlug is comparable to the Evergreen/ Deciduous Broad-leaved Mixed Forest zone of Mt. Emei (1500-2000 m alt., Li and Shi, 2007) (China 03), Sośnica to the Mt. Fuji, Vaccinium-Picea region (Japan 06), Mixed Mesophytic Forest from Southern Anhui Province (China 60), and Mixed Northern Hardwood Forest from Heilongjiang, Jilin and Liaoning Provinces (China 68).

Finally, Vonšov Mb. (Vildštejn Fm.-Pluto Clay) resembles the Evergreen/Deciduous Broad-leaved Mixed Forest zone of Mt. Emei (1500-2000 m alt., $\mathrm{Li}$ and Shi, 2007) (China 03) and Mixed Northern Hardwood Forest from Heilongjiang, Jilin and Liaoning Provinces (China 68) (see Table 2, Appendices 9 and 10).

The results derived by the Drudges (Table 2) summarised into higher-order vegetation types (Table 3) yield modern vegetation proxies for the older sites clearly concentrated in East Asia, mainly in the vegetation types BLEF in China (Staré Sedlo, Wackersdorf) and MMF of the Lower Yangtze Province (Seifhennersdorf). Parschlug is the only site with a strong focus on G-Thermophilous mixed deciduous broadleaved forests of Europe, though this signal is less distinct than the former two. For the sites Sośnica and Vonšov Mb. (Vildštejn Fm.-Pluto Clay), the signal is two-fold regarding the region, pointing to East Asia and Europe, and three-fold regarding the major vegetation types, i.e., mixed forests in China (Mixed mesophytic forest of the Lower Yangtze Province, Mt. Emei evergreen or deciduous broad-leaved mixed forest zone), BLDF (northern parts of China, F-Mesophytic broadleaved deciduous and mixed broad-leaved/conifer forests in Europe), as well as East Asian montane coniferous forests.

\section{Results Specific for Individual Test Sites}

For Staré Sedlo the IPR Similarity derived by Drudge 1 and Taxonomic Similarity (TS) are per se less consistent (Table 2), delivering a very wide range of European and East Asian units including C-Subarctic, boreal, and nemoral-montane open woodlands (C45-West Low Caucasian krummholz and open woodlands) to units of broad-leaved evergreen forests of Japan (Japan 07, 08), Montane Coniferous Forest of Taiwan sensu Wang
(1961) (China 89), and Meili Snow Mt. - Sclerophyllous, and Broad leaved forest zone (2580-3650 $m$ alt.) (China 13, 14). The proxy sets derived by both tools (IPR Similarity, TS, and Results - Mix), however, indicate predominantly East Asian affinity to vegetation units of the Broad-leaved Evergreen Sclerophyllous Forest sensu Wang (1961) (China 30, 32, 34, 36, 38).

For Seifhennersdorf the IPR Similarity proxy set derived by Drudge 1 also delivers no clear signal regarding East Asian or European affinity (Table 2). Otherwise, especially TS and the Results - Mix delivered by both Drudges point mostly towards Mixed Mesophytic Forests of the Lower Yangtze Province and Broad-leaved Deciduous Forests of the Upper Yangtze Province (China 56$58,60,61,67)$.

Similarly to Staré Sedlo and Seifhennersdorf, the IPR Similarity proxy set for Wackersdorf delivered by Drudge 1 is heterogeneous regarding region and vegetation type and therefore per se does not show a clear signal (Table 2). Comparing the results (IPR Similarity, TS and Results - Mix) derived by Drudge 1 and 2, mainly Broad-leaved Evergreen Sclerophyllous Forests of southern Hunan, Guizhou, northern Guangxi, Yunnan (China 35-38), Mixed Mesophytic Forests of the Lower Yangtze Province in Tianmu-Shan, Southern Anhui and Eastern Guizhou (China 57, 60), the Evergreen/Deciduous broad-leaved mixed forest zone of Mt. Emei (1500-2000 m alt.) (China 03) are indicated.

Among the test sites, Parschlug is the oldest in which the IPR Similarity yields an unambiguous signal towards modern European vegetation, in which units of G-Thermophilous mixed deciduous broadleaved forests (G30, G32, G43, G71, G74) are prevalent (Table 2). At the same time, TS unambiguously points to East Asia. The Results Mix proxy set from Drudge 1 indicates both East Asian and European affinity, and exclusively Asian affinity in Drudge 2.

For Sośnica, both tools deliver BLDF and MMF as forest type (IPR Similarity, TS, Results Mix) (Table 2). The IPR Similarity points essentially towards F-Mesophytic broadleaved deciduous and mixed broadleaved/conifer forests (F54, F65, F75, F130, F171) and to a lesser extent towards GThermophilous mixed deciduous broadleaved forests of Europe (G017, G018, G038). The Results Mix delivered by both tools share three units (China 60, 68, Japan 06).

Mainly broad-leaved deciduous forests in Europe and East Asia are delivered by the IPR 
Similarity, TS and Results - Mix of both tools for Vonšov Mb (Vildštejn Fm.)-Pluto Clay (Table 2). These units represent F-Mesophytic broadleaved deciduous and mixed broadleaved/conifer forests and G-Thermophilous mixed deciduous broadleaved forests of Europe (F033, F054, F069, F123, G038, G055), BLDF of the Upper Yangtze Province Western Hubei (China 62) and BLDF of Northeastern and Northern Provinces (Mixed Northern Hardwood Forest Northeastern Provinces, China 68, Oak Forest, China 71). Further results point towards vegetation at high altitudes both in Europe and China (Montane Boreal Coniferous Forest of the Northeastern Provinces (China 80, 81), Dinaric mountain pine scrub (C037), and Mixed Mesophytic Forests of the Lower Yangtze Province (China 61).

\section{DISCUSSION}

The developed tools Drudge 1 and Drudge 2 mathematically determine the closest analogues of a fossil plant assemblage out of the calibration dataset of modern plant units based on the correspondence in the proportion of zonal key components (IPR Similarity) and Taxonomic Similarity (TS). Both tools differ in so far as Drudge 1 takes into account only the proportions of the zonal woody key components (BLD, BLE, SCL+LEG of zonal woody angiosperms), while Drudge 2 also includes the zonal herb components (DRY and MESO HERB of all zonal taxa).

China 03 (Evergreen/Deciduous Broadleaved Mixed Forest zone of Mt. Emei, 1500-2000 $\mathrm{m}$ alt.) is the vegetation unit most commonly delivered by both tools. China 03 is part of the proxy sets of all test sites except for Staré Sedlo (Table 2). Its extraordinary high diversity (more than 630 zonal species) accounts for the least differential potential within the modern calibration set.

Based on Drudge 1 and 2, the low correspondence among the IPR Similarity modern vegetation proxy sets for the individual fossil sites (Table 2) indicates that closest modern vegetation analogues could not be determined reliably based solely on IPR Similarity. Importantly, the IPR vegetation analysis, which is the basis of the IPR Similarity, was originally designed to calculate the proportions of zonal woody key components as an expression of major zonal vegetation types. By introducing TS, the IPR vegetation analysis is extended to determine modern vegetation proxies.

Regarding regional relationships, IPR Similarity yielded consistent trends in both tools: for the older fossil sites (Staré Sedlo, Wackersdorf, Seif- hennersdorf), East Asian vegetation units dominate the proxy sets. In contrast, the similarity to European vegetation is higher for the younger ones, namely Parschlug, Sośnica, and Similarity, TS and Results - Mix of both tools for Vonšov Mb (Vildštejn Fm.)-Pluto Clay (Table 2). In other words, the proportions of major zonal woody angiosperm components (BLD, BLE, SCL+LEG) reflect closer leaf physiognomical properties to modern East Asian vegetation in the late Eocene to the early Miocene, but a closer similarity to modern Europe from the turn of the early to middle Miocene and thereafter. The results obtained by Drudge 2, which includes the zonal herb components (DRY and MESO HERB), also point to a rather distinct shift from East Asian to European vegetation units. Since leaf physiognomy is an expression of plant physiology related to climate, these results are taken to indicate climate change.

Continuous strong taxonomic ties to East Asia from the late Eocene to the late Pliocene are revealed by TS. The impoverishment of the European flora during the Quaternary Ice Age probably accounts for lower taxonomic correspondence with the modern flora of Europe. Such a divergence between the IPR Similarity and TS results has not been reported before. It suggests that the Neogene European vegetation cannot be closely related to single modern vegetation units in either of the geographical regions.

Interestingly, while the results derived by IPR Similarity and TS differ, the correspondence is much better using Results - Mix in both tools (Staré Sedlo and Seifhennersdorf 4 matches each, Wackersdorf and Sośnica 3 matches each). This indicates that the criteria applied in IPR Similarity on the one hand and TS on the other hand arrive at more stable results when applied jointly instead of separately. In those cases where IPR Similarity and TS point towards vegetation units in different geographical regions to be compared with the fossil record and low consistency of the "Results Mix" proxy sets based on both tools, the "Results Mix" proxy sets may be less reliable, e.g., Parschlug (1 match) and Vonšov Mb. Vildštejn Fm.Pluto Clay (2 matches).

Units of G-Thermophilous mixed deciduous broad-leaved forests of Europe prevail in the IPR Similarity proxy sets (both tools) for Parschlug (Tables 2 and 3). This vegetation type occurs in southern regions of Europe (see Bohn et al., 2004, map 13) under a seasonally dry climate. Units of F-Mesophytic broadleaved deciduous and mixed broadleaved/conifer forests (see Bohn et al., 2004, 
map 9) dominate the IPR Similarity proxy sets for Sośnica, indicating less seasonal changes in humidity than for vegetation type $\mathrm{G}$. Hence, the shifts in the proportions of zonal key components result in a shift from East Asian to European vegetation types as modern proxies, which are interpreted here to signal climate changes in this part of Europe.

In general, the proxy sets of modern vegetation calculated by the here-introduced tools, Drudge 1 and Drudge 2, retrace the overall vegetation change in Central Europe during the Palaeogene and Neogene from prevailingly BLEF (Staré Sedlo, late Eocene) to MMF (Seifhennersdorf, early Oligocene), BLEF-MMF (Wackersdorf, early Miocene), thermophilous BLDF (Parschlug, late early to early middle Miocene), BLDF-MMF (Sośnica, late Miocene), and BLDF-montane coniferous forest (Vonšov Mb.-Vildštejn Formation-Pluto Clay, late Pliocene) (Table 3).

\section{Comparison with Empirically and Quantitatively Derived Results}

The Staré Sedlo plant assemblage was floristically analysed by Knobloch et al. (1996). Later, Kvaček (2010) characterised it as "Broad-leaved evergreen riparian gallery forest", which was tested by the IPR vegetation analysis and Leaf Size Analysis typifying a subtropical lowland notophyllous BLEF as vegetation analogues for the Staré Sedlo Formation (Teodoridis et al., 2012). The modern vegetation units delivered by Drudge 1 and 2 (Table 2, Appendices 9 and 10; shared modern proxies China 30, 34, 36 in Results - Mix) compare Staré Sedlo with the vegetation type of BLEF - Taiwan (500-2000 m alt.), the Nantan region of northern Guangxi Province (1000-1500 m alt.), and the Wumong Shan area of SW Guizhou Province (Wang, 1961). This agrees with the empirically derived results. Based on applying the Climate Leaf Multivariate Program (CLAMP; Spicer, 2007) and Coexistence Approach (CA; Mosbrugger and Utescher, 1997), Staré Sedlo can be characterised by the following palaeoclimatical estimates: mean annual temperature (MAT) $16.2 / 15.7-23.9^{\circ} \mathrm{C}$, warmest month mean temperature (WMT) 25.9/ 25.6-28. $1^{\circ} \mathrm{C}$, coldest month mean temperature (CMT) $6.3 / 5-12.6^{\circ} \mathrm{C}$, and mean annual precipitation (MAP) n.a./1122-1613 mm (Teodoridis and Kvaček, 2015). This palaeoproxy climate dataset is close to that provided by Wang (1961) for SE China in the region occupied by BLEF vegetation, e.g., Guilin (Guangxi) MAT $19.3^{\circ} \mathrm{C}$, WMT $28.5^{\circ} \mathrm{C}$, CMT $7.8^{\circ} \mathrm{C}$, and MAP $1947.2 \mathrm{~mm}$.
Walther and Kvaček (2007) characterised the flora of Seifhennersdorf as diversified MMF. This was supported by the IPR vegetation analysis, which predicted transitional (ecotone) vegetation between MMF and BLDF with palaeoclimatic estimates derived by CLAMP and CA [MAT 11.3/15.6$16.6^{\circ} \mathrm{C}$, WMT $23.5 / 25.7-26.4^{\circ} \mathrm{C}$, CMT $0.7 / 5-$ $5.2^{\circ} \mathrm{C}$, MAP not applicable/700 mm (Teodoridis and Kvaček, 2015)]. The modern proxy sets derived by applying Drudge 1 and 2 (Table 2, Appendices 9 and 10) are situated in the Lower Yangtze Province (China 56, 57, 60; MMF-Southern Jiangsu, MMF-Tianmu-Shan and MMF-Southern Anhui) and in the Upper Yangtze Province (China 67, BLDF-Eastern Guizhou) (Wang, 1961).

The flora of Wackersdorf (Knobloch and Kvaček, 1976; Gregor, 1978, Günther and Gregor, 1993) represents a typical Younger Mastixioid flora characterised by a mixture of thermophilous zonal evergreen elements, e.g., Distylium, Trigonobalanopsis, Diplopanax, Mastixia, Lauraceae, and azonal elements, e.g., Glyptostrobus, Nyssa, Alnus, Acer, Fraxinus, Nymphea, and Spirematospermum. The zonal vegetation was interpreted as an ecotone between BLEF and MMF (Knobloch and Kvaček, 1976). The results derived by the new tools (Table 2, Appendices 9 and 10) point prevailingly towards Broad-leaved Evergreen Sclerophyllous Forests (China 35-38), Mixed Mesophytic Forests of the Lower Yangtze Province (China 57, 60), BLDF of the Upper Yangtze Province in Eastern Guizhou (China 67) (sensu Wang 1961), and Mount Emei - Evergreen/Deciduous Broad-leaved Mixed Forest zone (1500-2000 m alt.) (sensu Li and Shi 2007). Except for China 67, these results are in good agreement with the empirical ones. Teodoridis and Kvaček (2015) published palaeoclimatic proxies for Wackersdorf derived from the CLAMP/CA as followed: MAT $18 / 15.7-16.6^{\circ} \mathrm{C}$, WMT $26 / 24.9-26.0^{\circ} \mathrm{C}, \mathrm{CMT} 12.1 / 5.6-10.9 /{ }^{\circ} \mathrm{C}$, and MAP 1096-1187 mm.

Based on the floristic composition, the autecology of similar living relatives and leaf physiognomy, the zonal vegetation of Parschlug was described as subhumid forests with mixed mesophytic forests restricted to patches of humid mesophytic habitats under subtropical, probably less humid climate than in preceding and following periods (Kovar-Eder et al. 2004). Based on the IPR vegetation analysis the Parschlug flora was assigned to the ShSF (Kovar-Eder et al. 2008, Kovar-Eder and Teodoridis, 2018, Appendix 8). As IPR Similarity and TS point towards different regions (the former to Europe, the latter to East 
Asia) and because the match in Results - Mix of both tools is confined to a single unit - China 03 (Mt. Emei - Evergreen/Deciduous Broad-leaved Mixed Forest zone (1500-2000 m alt., Li and Shi, 2007 ), which has a very low discriminating potential due to its extraordinarily high diversity (see above), the Results - Mix are considered less reliable. The IPR Similarity of both Drudges indicates solely modern European vegetation units, whereby G-Thermophilous mixed deciduous broadleaved forests spread in southern parts of Europe dominate (G030, G032, G043, G071, G074, see Bohn et al., 2004, map 13, and Submediterranean floristic subregion; Meusel and Jäger, 1989). We therefore assume this vegetation type, which is related to climate with stronger seasonality in precipitation and somewhat warmer temperature regime than adjacent northern regions, to be most likely comparable with Parschlug. Less likely candidates are DMesophytic and hygromesophytic coniferous and mixed broad-leaved-coniferous forests and $\mathrm{K}$ Xerophytic coniferous forests, coniferous woodland and scrub, which are indicated by two units each (D 042, D 064, K 015, K 022), and F-Mesophytic broadleaved deciduous and mixed broadleaved/ conifer forests, which are indicated by one unit (F098). Unfortunately, climate proxy results are not available for Parschlug.

Detailed taxonomic studies provide insight into the late Miocene flora of Sośnica (Walther and Zastawniak, 1991, Zastawniak and Walther, 1998, Collinson et al., 2001, Kohlman-Adamska et al., 2004; Manchester and Zastawniak, 2007) in addition to the floristic characterisation by Goeppert (1855). The forest vegetation was characterised as mesophilous deciduous or mixed forests with variable species composition depending on soil humidity. Drier habitats are indicated by, e.g., Tetraclinis, Paliurus and legume-like leaflets (Collinson et al., 2001). Mai (1995) assigned this assemblage to the "Florenkomplex Cheylade", which he characterised by the occurrence of woody taxa occurring today in European deciduous forests and the depletion of thermophilous taxa. The IPR vegetation analysis indicates an ecotone between BLDF and MMF for Sośnica (Appendix 8). BLDF and MMF are the prevailing forest types delivered by both tools. The affinity to Europe is provided by the IPR Similarity, while TS and Results - Mix point towards closer Asian affinity. The European vegetation delivered is mainly F-Mesophytic broadleaved deciduous and mixed broadleaved/conifer forests and to a lesser extent G-Thermophilous mixed deciduous broadleaved forests of Europe (Table 2, Appendi- ces 9 and 10). For Sośnica neither CLAMP nor CA have been applied to derive climate proxies.

The plant assemblages from the Vonšov Mb.Pluto Clay of the Vildštejn Formation are characterised by a zonal assemblage indicating a mixed coniferous and broad-leaved deciduous forest, e.g., Pinus, Picea, Larix, Liriodendron, Quercus, Castanea, Taxus, and Ilex growing in mesic habitats (Bůžek et al., 1985). Those authors pointed out a relationship to modern vegetation types in North America (Weymouth pine mixed forests near the Taxodium alluvial forests with Nyssa, Acer rubrum, and various deciduous oaks and the Chamaecyparis swamp forests), and the sub-Mediterranean zone in Europe (Querco-Carpinetum betuli association, where Pinus peuce builds poor stands occupying higher mountain biotopes over $1500 \mathrm{~m}$ alt.). The differences in the IPR Similarity results - pointing more towards Asian affinity in Drudge 1 but to Europe in Drudge 2 - are essentially caused by the diversity of zonal herbs (>30\%) (Table 2, Appendices 9 and 10). Broad-leaved deciduous forest types and montane coniferous forests as indicated by both tools appear reasonable. The regional affinity to European and Asian vegetation may be biased, bearing in mind that North American modern vegetation is not assessed by the approach presented here.

According to Teodoridis et al. (2017), the palaeoclimate proxies for the plant assemblage of the Vonšov Member indicated by CA are MAT $15.6-15.8^{\circ} \mathrm{C}$, WMT $24.7-24.9^{\circ} \mathrm{C}$, CMT $5-5.6^{\circ} \mathrm{C}$, and MAP 823-900 $\mathrm{mm}$. The gridded climatic parameters for $1500 \mathrm{~m}$ altitude at Mt. Emei are similar, i.e., MAT $14.2^{\circ} \mathrm{C}$, WMT $22.7^{\circ} \mathrm{C}$, CMT $4.8^{\circ} \mathrm{C}$, and MAP $969 \mathrm{~mm}$ (Teodoridis et al., 2011b, table 6).

\section{CONCLUSIONS}

So far, the IPR vegetation analysis has served to derive major types of zonal palaeovegetation based on the proportion of zonal key components in fossil plant assemblages. This method is enhanced by introducing the parameter Taxonomic Similarity (TS) at generic level and by considerably extending the calibration dataset of modern vegetation for Europe, the Caucasus, China, and Mongolia. This calibration set now includes 505 units. The tools Drudge 1 and Drudge 2 are introduced as user-friendly tools to determine close modern vegetation proxies for fossil plant assemblages. These tools calculate the correspondence of fossil plant assemblages to modern vegetation units based on IPR Similarity and TS. IPR Similarity is 
the correspondence of the proportions of key zonal components. Drudge 1 incorporates the zonal woody angiosperm components (BLD, BLE, SCL+LEG of woody angiosperms) and TS. Drudge 2 further includes the zonal herb components (DRY HERB, MESO HERB of all zonal components).

Drudge 1 and 2 were tested on six selected Central European floras ranging from the late Eocene to the late Pliocene. The results reflect the overall vegetation change that occurred in Central Europe during the Palaeogene and Neogene from prevailingly BLEF (Staré Sedlo, late Eocene) to MMF (Seifhennersdorf, early Oligocene), BLEFMMF (Wackersdorf, early Miocene), ShSF-BLDF (Parschlug, late early to early middle Miocene), BLDF-MMF (Sośnica, late Miocene), and BLDFmontane coniferous forest (Vonšov Mb.-Pluto Clay of the Vildštejn Formation, late Pliocene). The results indicate a shift from Asian to European affinity in the proportions of zonal key components, i.e., leaf physiognomy of woody angiosperms, at the turn of the early/middle Miocene. In a global perspective this transformation may be related to the overall shift from greenhouse to icehouse climates during the Neogene (Zachos et al., 2001). TS, in contrast to IPR Similarity, consistently points towards Asian affinity. These divergent trends are reported here for the first time and underline that modern vegetation should serve only as rough proxies rather than for direct correlation of the fossil record with single regional modern vegetation units.

\section{ACKNOWLEDGEMENTS}

We thank I. Gabrielyan (National Academy of Sciences of Armenia, Yerevan) for advice on scoring Caucasian plant assemblages and Angela A. Bruch for helpful comments and long discussions. We are thankful to L. Kunzmann and T. Denk for their comments on the first version of the manuscript and two anonymous reviewers for their careful work. This study was supported by the grant projects of GAČR No. P18-25057S and of Charles University, Prague, Progres Q17.

\section{REFERENCES}

Bohn, U., Neuhäusı, R., Gollub, G., Hettwer, C., Neuhäuslová, Z., Raus, Th., Schlüter, H., and Weber, H. 2004. Map of the Natural Vegetation of Europe. Maßstab / Scale 1:2500000. Landwirtschaftsverlag, Münster. online available as: EuroVegMap 2.06 (http:// www.floraweb.de/vegetation/dnld_eurovegmap.html)

Bůžek, Č., Kvaček, Z., and Holý, F. 1985. Late Pliocene palaeoenvironment and correlation of the Vildštejn floristic complex within Central Europe. Rozpravy ČSAV, Řada matematickoprírodních věd, 95:1-72.

Collinson, M., Kvaček, Z., and Zastawniak, E. 2001. The aquatic plants Salvinia (Salviniales) and Limnobiophyllum (Arales) from the late Miocene flora of Sośnica (Poland). Acta Palaeobotanica, 41:253-282.

Goeppert, H.R. 1855. Die tertiäre Flora von Schossnitz in Schlesien. Heynische Buchhandlung (E. Remer), Görlitz.

Gregor, H.J. 1978. Die miozänen Frucht- und Samen-Floren der Oberpfälzer Braunkohle. I. Funde aus den sandigen Zwischenmitteln. Palaeontographica Abt. B, 167:9-103.

Günther, Th. and Gregor, H.J. 1993. Computeranalyse neogener Frucht- und Samenfloren Europas. Documenta naturae, 50(4):1-190.

Kohlman-Adamska, A., Ziembińska-Tworzydło, M., and Zastawniak, E. 2004. In situ pollen in some flowers and inflorescences in the Late Miocene flora of Sośnica (SW Poland). Review of Palaeobotany and Palynology, 132:261-280. https://doi.org/10.1016/ j.revpalbo.2004.07.005

Knobloch, E., Konzalová, M., and Kvaček, Z. 1996. Die obereozäne Flora der Staré SedloSchichtenfolge in Böhmen (Mitteleuropa). Rozpravy Českého Geologického Ústavu, 49:1260.

Knobloch, E. and Kvaček, Z. 1976. Miozäne Blätterfloren vom Westrand der Böhmischen Masse. Rozpravy Ústředního Geologického Ústavu, 42:1-129.

Kovar-Eder, J., Jechorek, H., Kvaček, Z., and Parashiv, V. 2008. The integrated plant record: an essential tool to reconstruct Neogene zonal vegetation in Europe. Palaios, 23:97-111. https:// doi.org/10.2110/palo.2006.p06-039r 
Kovar-Eder, J. and Kvaček, Z. 2003. Towards vegetation mapping based on the fossil plant record. Acta Universitatis Carolinae, Geologica, 46(4):7-13.

Kovar-Eder, J. and Kvaček, Z. 2007. The integrated plant record (IPR) to reconstruct Neogene vegetation - the IPR vegetation analysis. Acta Palaeobotanica, 47(2):391-418.

Kovar-Eder, J., Kvaček, Z., and Ströbitzer-Hermann, M. 2004. The Miocene flora of Parschlug (Styria, Austria) - revision and synthesis. Annalen des Naturhistorischen Museums in Wien, 105A:45-159.

Kovar-Eder, J. and Teodoridis, V. 2018. The Middle Miocene Central European plant record revisited; widespread subhumid sclerophyllous forests indicated. Fossil Imprint, 74:115-134. https://doi.org/10.2478/if-2018-0009

Kvaček, Z. 2010. Forest flora and vegetation of the European early Palaeogene - a review. Bulletin of Geosciences, 85:63-76. https://doi.org/10.3140/bull.geosci.1146

Li, Z.Y. and Shi, L. 2007. Plant of Mount Emei. Beijing Science \& Technology Press, Beijing.

Mai, D.H. 1995. Tertiäre Vegetationsgeschichte Europas. Gustav Fischer, Jena, Stuttgart, New York.

Manchester, S.R. and Zastawniak, E. 2007. Fruit with perianth remains of Chaneya Wang \& Manchester (extinct Rutaceae) in the Upper Miocene of Sośnica, Poland. Acta Palaeobotanica, 47:253-259.

Martinetto, E. and Vassio, E. 2009. Reconstructing "Plant Community Scenarios" by means of palaeocarpological data from the CENOFITA database, with an example from the Ca'Viettone site (Pliocene, Northern Italy). Quaternary International, 225:25-36. https:// doi.org/10.1016/j.quaint.2009.08.020

Meusel, H. and Jäger, E.J. 1989. Ecogeographical differentiation of the Submediterranean deciduous forest flora. Plant Systematics and Evolution, 162:315-329.

Mosbrugger, V. and Utescher, T. 1997. The coexistence approach - a method for quantitative reconstructions of Tertiary terrestrial palaeoclimate data using plant fossils. Palaeogeography, Palaeoclimatology, Palaeoecology, 134:61-86. https://doi.org/10.1016/ s0031-0182(96)00154-x

Spicer, R.A. 2007. Recent and future of CLAMP: Building on the legacy of Jack A. Wolfe. Courier Forschungsinstitut Senckenberg, 258:109-118.

Stachurska, A., Sadowska, A., and Dyjor, S. 1973. The Neogene Flora at Sośnica near Wrocław in the light of geological and palynological investigations. Acta Palaeobotanica, 14:147-176.

Stuchlik, L. 1982. Rostlinné mikrofosílie vildštejnského souvrství (chebská pánev). Časopis pro mineralogii a geologii, 27(3):301-307.

Teodoridis, V., Bruch, A.A., Martinetto, E., Vassio, E., Kvaček, Z., and Stuchlik, L. 2017. PlioPleistocene floras of the Vildštejn Formation in the Cheb Basin, Czech Republic - a review and a new paleoenvironmental evaluation. Palaeogeography, Palaeoclimatology, Palaeoecology, 467:166-190. https://doi.org/10.1016/j.palaeo.2015.09.038

Teodoridis, V., Kovar-Eder, J., Marek, P., Kvaček, Z., and Mazouch, P. 2011a. The Integrated Plant Record vegetation analysis - a new on-line application. Acta Musei Nationalis Pragae, Series B - Historia Naturalis, 37(3-4):159-165.

Teodoridis, V., Kovar-Eder, J., Marek, P., Kvaček, Z., and Mazouch, P. IPR database, 2011-2019. IPR database http://www.iprdatabase.eu/. Faculty of Education, Charles University, Prague.

Teodoridis, V., Kovar-Eder, J., and Mazouch, P. 2011b. The IPR-vegetation analysis applied to modern vegetation in SE China and Japan. Palaios, 26:623-638. https://doi.org/10.2110/ palo.2010.p10-149r

Teodoridis, V. and Kvaček, Z. 2015. Palaeoenvironmental evaluation of Cainozoic plant assemblages from the Bohemian Massif (Czech Republic) and adjacent Germany. Bulletin of Geosciences, 90(3):695-720. https://doi.org/10.3140/bull.geosci.1553

Teodoridis, V., Kvaček, Z., Zhu, H., and Mazouch, P. 2012. Environmental analysis of the midlatitudinal European Eocene sites of plant macrofossils and their possible analogues in East Asia. Palaeogeography, Palaeoclimatology, Palaeoecology, 333-334:40-58. https://doi.org/ 10.1016/j.palaeo.2012.03.008

Utescher, T., Erdei, B., François, L., and Mosbrugger, V. 2007. Tree diversity in the Miocene forests of Western Eurasia. Palaeogeography, Palaeoclimatology, Palaeoecology, 253:226250. https://doi.org/10.1016/j.palaeo.2007.03.041

Walther, H. and Kvaček, Z. 2007. Early Oligocene flora of Seifhennersdorf (Saxony). Acta Musei Nationalis Pragae, Series B - Historia Naturalis, 63(2-4):85-174. 
Walther, H. and Zastawniak, E. 1991. Fagaceae from Sośnica and Malczyce (near Wrocław, Poland). A revision of original materials by Goeppert 1852 and 1855 and a study of new collections. Acta Palaeobotanica, 31:153-199.

Wang, Ch.-W. 1961. The forests of China with a survey of grassland and desert vegetation. Maria Moors Cabot Foundation Publication Series, 5:1-313.

Zachos, J., Pagani, M., Sloan, L. Thomas, E., and Billups. K. 2001. Trends, rhythms, and aberrations in global climate $65 \mathrm{Ma}$ to present. Science, 292:686-693.

Zastawniak, E. and Walther, H. 1998. Betulaceae from Sośnica near Wrocław (Poland) - a revision of Goeppert's original materials and a study of more recent collections. Acta Palaeobotanica, 38:87-145. 


\section{APPENDICES.}

All appendices are grouped into a zipped file for download at https://palaeo-electronica.org/content/2020/2992-advances-in-ipr-analysis.

\section{APPENDIX 1.}

Reference dataset of modern European vegetation mapping units marked "C1-47" and "D1D64" (sensu Bohn et al., 2004) with lists of plant taxa, scoring according to the IPR vegetation analysis, and results.

\section{APPENDIX 2.}

Reference dataset of European modern vegetation mapping units marked "F1-F172" (sensu Bohn et al., 2004) with lists of plant taxa, scoring according to the IPR vegetation analysis, and results.

\section{APPENDIX 3.}

Reference dataset of European modern vegetation mapping units marked "G1-G77, H1-H3, J1J53, K1-K33, L1-L17, M1-M21, N1-N8, O1-O9” (sensu Bohn et al., 2004) with lists of plant taxa, scoring according to the IPR vegetation analysis, and results.

\section{APPENDIX 4.}

Reference dataset of Chinese and Japanese modern vegetation units (sensu Teodoridis et al., 2011a, 2012) and vegetation units from China and Mongolia (sensu Wang, 1961) containing lists of plant taxa and their scoring according the IPR vegetation analysis, and results.

\section{APPENDIX 5.}

Copy and paste application of Drudge 1 including taxa, IPR scoring, and results for the early Oligocene plant assemblage of Seifhennersdorf (Germany).

\section{APPENDIX 6.}

Copy and paste application of Drudge 2 including taxa, IPR scoring, and results for the early Oligocene plant assemblage of Seifhennersdorf (Germany).

\section{APPENDIX 7.}

Vegetation units from Europe and the Caucasus (Bohn et al., 2004), China and Mongolia (Wang, 1961), China and Japan (Teodoridis et al. 2011b, Teodoridis et al. 2012). Linkage of ID codes and the designation of the modern plant units.

\section{APPENDIX 8A-E.}

Selected European floras from the late Eocene to late Pliocene (test set) with list of taxa and 
score sheet according to the IPR vegetation analysis. Appendix 8A Staré Sedlo, Appendix 8B Seifhennersdorf, Appendix 8C Wackersdorf, Appendix 8D Parschlug, Appendix 8E Sośnica, Appendix 8F Vonšov Mb. (Vildštejn Fm.-Pluto Clay).

\section{APPENDIX 9A AND B.}

Synthesis of the IPR Similarity, Taxonomic Similarity, and Results - Mix for the sites of the test set derived by applying Drudge 1 (Appendix 9A) and 2 (Appendix 9B), supplemented by the designations of the modern vegetation units.

\section{APPENDIX 10A AND B.}

Synthesis of the IPR Similarity and Results - Mix for the sites of the test set derived by applying Drudge 1 (Appendix 10A) and 2 (Appendix 10B), supplemented by the scoring results of the key zonal components according to the IPR vegetation analysis. 